\title{
Efficient One-Pot Synthesis of Triazole-Linked Morpholinone Scaffolds by CuAAC in the Presence of 18-Crown-6
}

\author{
A. Mayooufia,b \\ M. Romdhani-Younes ${ }^{b}$ \\ J. Thibonnet*a \\ ${ }^{a}$ Laboratoire Synthèse et Isolement de Molécules BioActives \\ (SIMBA), EA7502, Université de Tours, Faculté des Sciences et \\ Techniques, Parc de Grandmont, 32 av. Monge, 37200 Tours, \\ France \\ jerome.thibonnet@univ-tours.fr \\ b Laboratoire de Chimie Organique Structurale et Macromolécu- \\ laire, Département de Chimie, Faculté des Sciences de Tunis, \\ Campus Universitaire El-Manar, Rue Béchir Salem Belkheiria, \\ 2092 Tunis, Tunisie
}

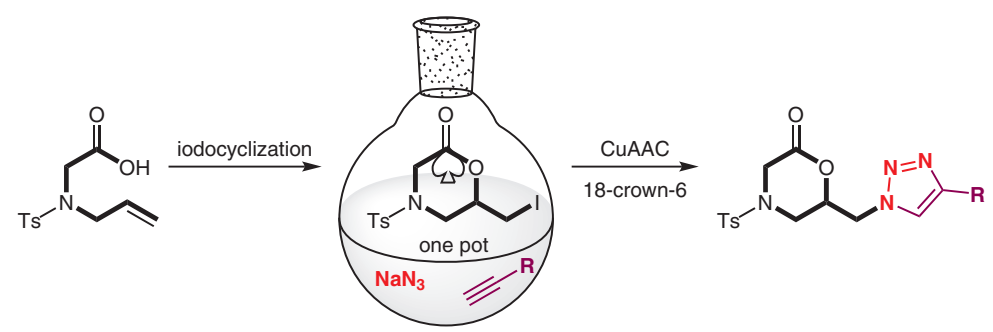

Received: 08.10.2018

Accepted after revision: 02.11.2018

Published online: 22.11 .2018

DOI: 10.1055/s-0037-1610399; Art ID: so-2018-d0052-op

License terms: cc)

Abstract $A$ range of bis-heterocyclic derivatives based on novel morpholinone and triazole heterocycles was prepared from iodomorpholinone. The key step in our strategy is a one-pot procedure based upon copper-catalysed alkyne-azide cycloaddition (CuAAC) from iodo-morpholinone.

Key words click chemistry, iodolactonization, morpholinones, azides, 1,2,3-triazole, one-pot procedure

The synthesis of five- and six-membered nitrogencontaining heterocycles, such as morpholinones and 1,2,3triazoles, has received considerable attention, and these structures constitute important classes of biologically active compounds.

Various morpholinone-containing compounds have been reported in the past decade with a range of biological properties (Scheme 1). For example, compound $\mathbf{A}$ exhibits antifungal and antibacterial activities against four bacteria and seven fungal species ${ }^{1}$ and morpholinone $\mathbf{B}$ was recently found to be an inhibitor of the MDM2-p53 protein-protein interaction. ${ }^{2}$ It is important to note that 1,2,3-triazole based heterocycles have become a cornerstone of medicinal chemistry because of their important biological activities. For example, compound $\mathbf{C}$ exhibits potent anticancer activity, ${ }^{3}$ compound $\mathbf{D}$ was found to have good TNF- $\alpha$ inhibitory activity, ${ }^{4}$ antiviral compound $\mathbf{E}$ exhibits cytostatic activity in the high micromolar range, ${ }^{5}$ and compound $\mathbf{F}$ shows potent antibacterial activity against both Gram-positive and Gram-negative bacteria. ${ }^{6}$ In addition, a series of thiazolidinediones with triazole substitution show antidiabetic and anticancer activity properties. ${ }^{7}$
Given the promising biological properties and synthetic applications of these heterocycles, it appeared interesting to consider the combination of these moieties, with the aim to access novel more biologically effective compounds. As a consequence, the development of effective and practical methods for the construction of morpholines with 1,2,3triazoles units appeared to be a worthwhile goal.

In our previous work, we have synthesized numerous heterocycles by using coupling/cyclization tandem reactions. ${ }^{8}$ In a continuation of our research devoted to the development and diversification of new classes of heterocycles, we report herein the construction of iodomorpholinone 5 through electrophilic iodocyclization of acid $\mathbf{2}$. In addition, introduction of an iodo- functionality provides a useful route for the synthesis of novel morpholinones, incorporating the 1,2,3-triazole moiety, with good yields.

Initially, the starting acids $\mathbf{2}$ and $\mathbf{4}$ were prepared from allylamine in three steps (Scheme 2). Allylamine was tosylated under standard conditions, providing the corresponding tosyl-functionalized amine. This amine was then alkylated by following Raghunathan's protocol using ethyl bromoacetate, affording ethyl $N$-allyl- $N$-tosylglycinate $\mathbf{1}$ in $80 \%$ yield over two steps. ${ }^{9}$ Saponification of ester 1 was achieved using $12 \% \mathrm{KOH}$, leading to the corresponding acid $\mathbf{2}$ in quantitative yield. The synthesis of compound $\mathbf{4}$ was achieved in two steps. First, the $\mathrm{N}$-tosylated allyl amine was reacted with methyl acrylate in $\mathrm{MeCN}$ in the presence of a substoichiometric amount of 1,8-diazabicyclo[5.4.0]undec7-ene (DBU), resulting in an aza-Michael addition reaction, as developed by Kim's group. ${ }^{10}$ Having synthesized the ester 3 in good yield (88\%), the next task was to convert the ester into its corresponding acid. The saponification of ester $\mathbf{3}$ was achieved with $\mathrm{LiOH}$ in a $\mathrm{MeOH} / \mathrm{H}_{2} \mathrm{O}$ mixture to afford the desired acid $\mathbf{4}$ in quantitative yield. Compounds $\mathbf{3}$ and $\mathbf{4}$ were characterized by comparison with the published NMR spectra (see the Supporting Information). ${ }^{11,12}$ 

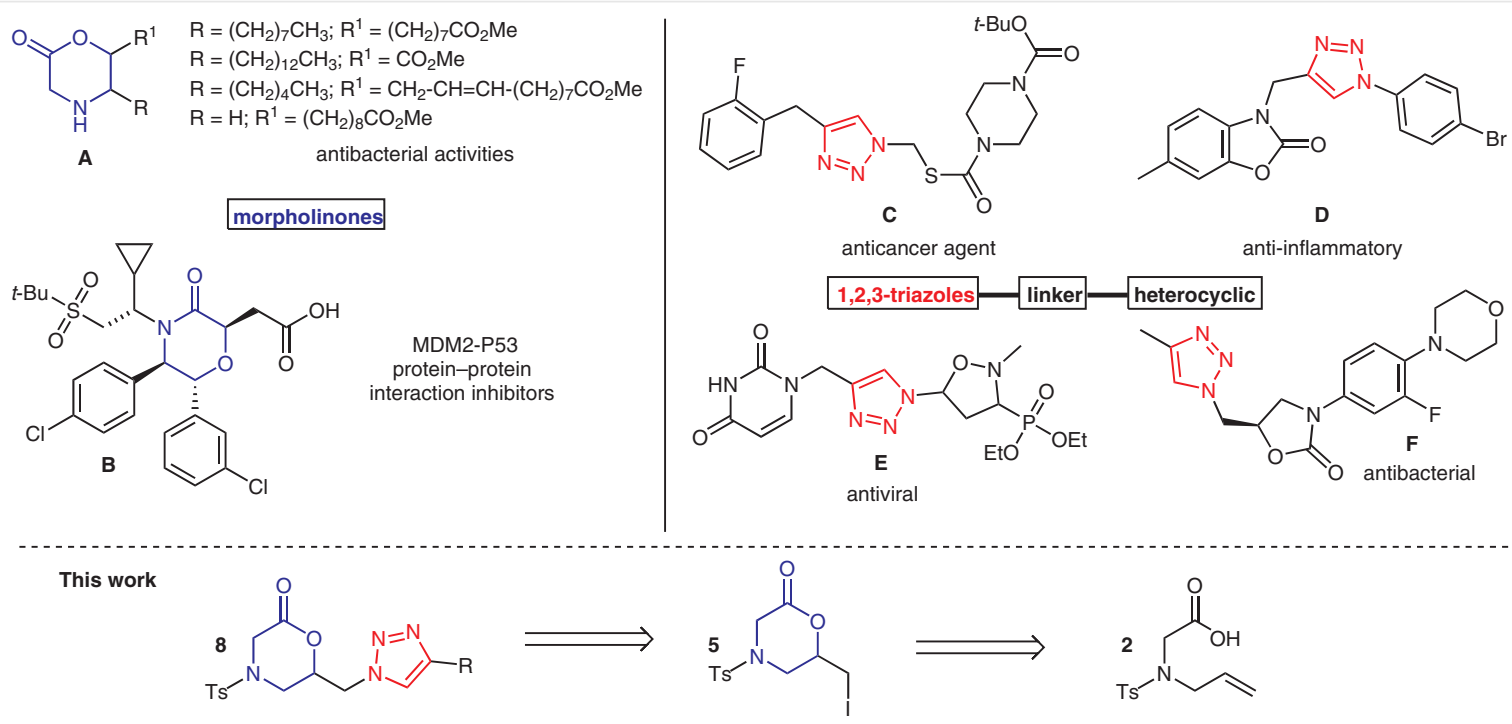

Scheme 1 Selected biologically active triazole and morpholinone units and retrosynthetic strategy for the sequential synthesis of morpholinones incorporating the 1,2,3-triazole moiety

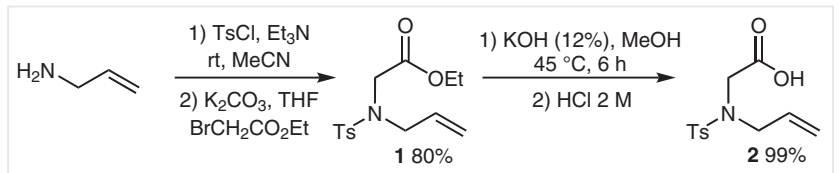

$$
\text { 2) }
$$

Scheme 2 Preparation of acids 2 and 4

We next explored the reactivity of amino acid $\mathbf{2}$ in the iodolactonization reaction. Iodocyclization of alkynes or alkenes represents a useful method for the preparation of important heterocycles, and a number of methods have been reported for the construction of functionalized cyclic compounds through halolactonization such as azetidines and pyrrolidines, ${ }^{13}$ benzo[a]phenazines, ${ }^{14}$ lactones, ${ }^{15}$ oxazolidin-2-ones, ${ }^{16}$ and other heterocycles. ${ }^{17}$ The results of the iodolactonization of $\mathbf{2}$ are presented in Table 1. Initial experiments were carried out using $\mathrm{I}_{2}$ (2 equiv) as the electrophile and $\mathrm{Na}_{2} \mathrm{CO}_{3}$ (3 equiv) as the base in $\mathrm{CHCl}_{3}$ at room temperature (entry 1 ). Under these conditions, iodo-morpholinone $\mathbf{5}$ was obtained while some starting material remained (20\%). We further tested $\mathrm{ICl}, \mathrm{N}$-bromosuccinimide (NBS) and NIS as electrophiles instead of iodine in this reaction without changing other factors (entries 2-4) but a decrease in the yield of the desired product $\mathbf{5}$ was noted along with $20 \%$ of starting material remaining. Only a complex mixture was obtained on increasing the temperature and only traces of the desired product 5 were isolated (entry 5). Changing $\mathrm{CHCl}_{3}$ to tetrahydrofuran (THF) gave a similar re- sult (entry 6). Different bases, such as $\mathrm{NaH}$ and $\mathrm{NaOH}$ (entries 7-8) gave similar results, while no reaction occurred when $\mathrm{Et}_{3} \mathrm{~N}$ was used as the base. However, we were pleased to find that the addition of $\mathrm{AgNO}_{3}$ (1 equiv) provided 5 selectively and in high yield (86\%) (entry 10). ${ }^{18}$ Subsequent testing showed that increasing the quantity of $\mathrm{AgNO}_{3}$ did not improve the yield (entry 11). On the basis of these results, the optimum conditions were established as $\mathrm{Na}_{2} \mathrm{CO}_{3}$ ( 2 equiv), $\mathrm{I}_{2}$ (1.5 equiv) and $\mathrm{AgNO}_{3}$ ( 1 equiv) in $\mathrm{CHCl}_{3}$ at room temperature (entry 12). Addition of silver nitrate probably allows an ionic reaction, ${ }^{19}$ and precipitation of $\mathrm{AgI}$ from the reaction medium will prevent iodide attacking the intermediate 5', avoiding the formation of bis-iodinated byproducts. Subsequently, regioselective intramolecular nucleophilic attack of the oxygen then proceeds via a 6-exo-tetring-closing pathway to form iodo-morpholinone $\mathbf{5}$.

The successful synthesis of iodomorpholinone $\mathbf{5}$ led us to investigate the iodocyclization of 3-aminopropanoic acid 4. Thus, acid 4 was treated with $\mathrm{I}_{2}$ (1.5 equiv), $\mathrm{Na}_{2} \mathrm{CO}_{3}$ (2 equiv) and $\mathrm{AgNO}_{3}$ (1 equiv) in $\mathrm{CHCl}_{3}$ at $25^{\circ} \mathrm{C}$ and, after 2 hours, complete iodolactonization was achieved, leading to the iodo-1,4-oxazepan-7-one $\mathbf{6}$ in 56\% yield (Scheme 3). It should be noted that product $\mathbf{6}$ is unstable. This product must be immediately purified, and it degrades quickly even when stored in the refrigerator.

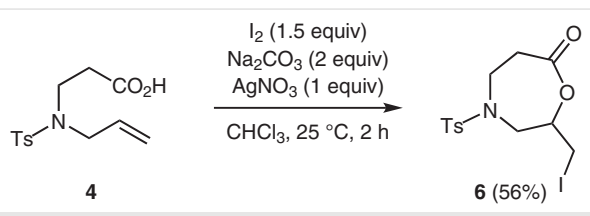

Scheme 3 lodocyclization of acid 4 
Table 1 Optimization of lodocyclization<smiles>C=CCN(C)CC(=O)O</smiles><smiles>C#CCCCCC</smiles><smiles>O=C1CN([13F])CC(CI)O1</smiles>

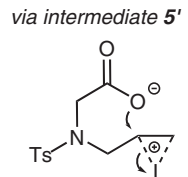

\begin{tabular}{|c|c|c|c|c|c|c|}
\hline $\begin{array}{l}\text { En- } \\
\text { try }\end{array}$ & $\begin{array}{l}\text { Electro- } \\
\text { phile } \\
\text { (equiv) }\end{array}$ & Solvent & Base (equiv) & $\begin{array}{l}\text { Temp } \\
\left({ }^{\circ} \mathrm{C}\right)\end{array}$ & $\begin{array}{l}\text { Additive } \\
\text { (equiv) }\end{array}$ & Yield (\%) \\
\hline 1 & $\mathrm{I}_{2}(2)$ & $\mathrm{CHCl}_{3}$ & $\mathrm{Na}_{2} \mathrm{CO}_{3}(3)$ & rt & - & 55 \\
\hline 2 & NBS (2) & $\mathrm{CHCl}_{3}$ & $\mathrm{Na}_{2} \mathrm{CO}_{3}(3)$ & 50 & - & $-^{\mathrm{b}}$ \\
\hline 3 & $\mathrm{ICl}(2)$ & $\mathrm{CHCl}_{3}$ & $\mathrm{Na}_{2} \mathrm{CO}_{3}(3)$ & rt & - & 50 \\
\hline 4 & NIS (2) & $\mathrm{CHCl}_{3}$ & $\mathrm{Na}_{2} \mathrm{CO}_{3}(3)$ & rt & - & 43 \\
\hline 5 & $\mathrm{I}_{2}(2)$ & $\mathrm{CHCl}_{3}$ & $\mathrm{Na}_{2} \mathrm{CO}_{3}(3)$ & 50 & - & trace $^{c}$ \\
\hline 6 & $\mathrm{I}_{2}(2)$ & THF & $\mathrm{Na}_{2} \mathrm{CO}_{3}(3)$ & $\mathrm{rt}$ & - & 51 \\
\hline 7 & $\mathrm{I}_{2}(2)$ & $\mathrm{CHCl}_{3}$ & $\mathrm{NaH}(1.5)$ & 0 & - & 48 \\
\hline 8 & $\mathrm{I}_{2}(2)$ & $\mathrm{CHCl}_{3}$ & $\mathrm{NaOH}(3)$ & 50 & - & 45 \\
\hline 9 & $\mathrm{I}_{2}(2)$ & $\mathrm{CHCl}_{3}$ & $\mathrm{Et}_{3} \mathrm{~N}(3)$ & $\mathrm{rt}$ & - & $-\mathrm{b}$ \\
\hline 10 & $\mathrm{I}_{2}(2)$ & $\mathrm{CHCl}_{3}$ & $\mathrm{Na}_{2} \mathrm{CO}_{3}(3)$ & rt & $\mathrm{AgNO}_{3}(1)$ & 86 \\
\hline 11 & $\mathrm{I}_{2}(2)$ & $\mathrm{CHCl}_{3}$ & $\mathrm{Na}_{2} \mathrm{CO}_{3}(3)$ & rt & $\mathrm{AgNO}_{3}(1.5)$ & 84 \\
\hline 12 & $\mathrm{I}_{2}(1.5)$ & $\mathrm{CHCl}_{3}$ & $\mathrm{Na}_{2} \mathrm{CO}_{3}(2)$ & $\mathrm{rt}$ & $\mathrm{AgNO}_{3}(1)$ & 86 \\
\hline
\end{tabular}

a Isolated yield after column chromatography.

b Starting material.

c Complex mixture.

We then focused on the installation of 1,2,3-triazole groups into the morpholinone scaffold through CuAACbased multicomponent reactions (MCR). MCRs are important and effective in carbon-nitrogen bond formation because of their considerable economic and ecological interests. ${ }^{20}$ These reactions have become important tools for the organic chemist to generate complex molecules that find many applications in drug discovery. ${ }^{21}$ In this context, the reactivity of halomorpholinones has been widely studied with sodium azide and terminal alkynes by using this onepot two-step sequence. Although we tested various conditions for the synthesis of 1,2,3-triazoles that are described in the literature, in our case no desired product was observed. ${ }^{22}$ On the basis of these results, we turned our attention to the preparation of novel morpholinones, incorporating the 1,2,3-triazoles moiety through the more classical two-step route, as shown in Scheme 4.

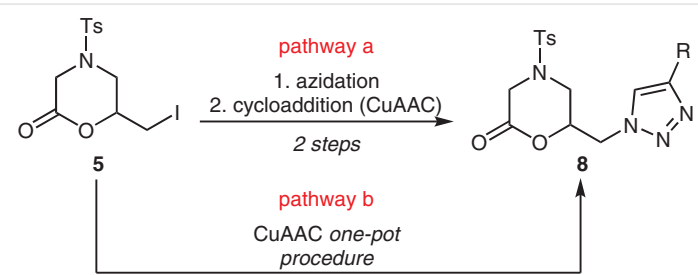

Scheme 4 Synthetic routes towards triazole-linked morpholinone 8
Thus, we examined nucleophilic substitution of the remaining iodide to introduce the azide group. ${ }^{13,23}$ In our initial attempt, we tested the influence of the solvent (Table 2 , entries 1-3 and entries 6-7) and found that protic solvents, such as $\mathrm{H}_{2} \mathrm{O}$ and $\mathrm{MeOH}$, led to degradation of product 7 , while the use of aprotic solvents, such as acetone, DMF and $\mathrm{MeCN}$ resulted in a low yield of $\mathbf{7}(30 \%)$. Moreover, we found that heating the reaction only afforded a complex mixture (entries 4 and 8). An increase in the quantity of $\mathrm{NaN}_{3}$ and reaction time did not improve the yield of this reaction (entry 5 ). In an attempt to increase the yield of $\mathbf{7}$, we treated iodo-morpholinone $\mathbf{5}$ with sodium azide in the presence of various additives (entries 9-11) ) $^{4}$ and found that product 7 could be obtained from 5 in a very high yield $(90 \%)$ in the presence of 18-crown-6. However, further investigation showed that, whereas increasing the amount of the latter reduces the reaction time, it did not give a better yield (entries 12 and 13). In this context, it is important to note that various attempts to introduce an azide group into substrates produced by iodolactonization are reported in the literature to result in incomplete reaction. ${ }^{13}$ Unfortunately, the iodo-1,4-oxazepan-7-one $\mathbf{6}$, in contrast to iodomorpholinone 5, could not be transformed into the desired

Table 2 Optimization Studies of the Reaction between Sodium Azide and Morpholinone $\mathbf{5}$

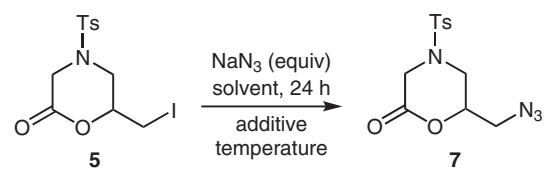

\begin{tabular}{llllll}
\hline Entry & Additive (equiv) & Solvent & $\begin{array}{l}\mathrm{NaN}_{3} \\
(\text { equiv) }\end{array}$ & $\begin{array}{l}\text { Temp } \\
\left({ }^{\circ} \mathrm{C}\right)\end{array}$ & Yield (\%) $^{\mathrm{a}}$ \\
\hline 1 & - & $\mathrm{MeOH} / \mathrm{H}_{2} \mathrm{O}$ & 3 & $\mathrm{rt}$ & $-^{\mathrm{b}}$ \\
2 & - & $\mathrm{MeOH}$ & 3 & 60 & $-^{\mathrm{b}}$ \\
3 & - & acetone & 3 & $\mathrm{rt}$ & $30^{\mathrm{c}}$ \\
4 & - & acetone & 3 & 45 & $-{ }^{\mathrm{b}}$ \\
5 & - & acetone & 6 & $\mathrm{rt}$ & $30^{\mathrm{c}, \mathrm{d}}$ \\
6 & - & DMF & 3 & $\mathrm{rt}$ & $30^{\mathrm{c}}$ \\
7 & - & MeCN & 3 & $\mathrm{rt}$ & $30^{\mathrm{c}}$ \\
8 & - & DMF & 3 & 75 & $-{ }^{\mathrm{b}}$ \\
$\mathbf{9}$ & $\mathbf{1 8 - c r o w n - 6 ( 0 . 5 )}$ & acetone & $\mathbf{3}$ & $\mathrm{rt}$ & $\mathbf{9 0}$ \\
10 & TBAl (0.5) & acetone & 3 & $\mathrm{rt}$ & 72 \\
11 & TBAF (0.5) & acetone & 3 & $\mathrm{rt}$ & 70 \\
12 & $18-c r o w n-6(1)$ & acetone & 3 & $\mathrm{rt}$ & $90^{\mathrm{e}}$ \\
13 & 18-crown-6(1.5) & acetone & 3 & $\mathrm{rt}$ & $90^{\mathrm{e}}$ \\
\hline
\end{tabular}

a Isolated yield.

b Degradation.

c Starting material 5 was recovered in 30\% yield.

d $72 \mathrm{~h}$ (time of reaction).

e $18 \mathrm{~h}$ (time of reaction). 
azide product under these conditions (in the presence of 18-crown-6), presumably because of the instability of the iodo-1,4-oxazepan-7-one 6.

In the next phase of the study, we wished to generate 1,2,3-triazole derivatives involving a 1,3-dipolar cycloaddition using azido morpholinone $\mathbf{7}$ as the starting material. Many protocols for the synthesis of 1,2,3-triazoles based on copper(I) catalysts have been reported. ${ }^{25}$ In our initial attempt, $\mathrm{CuSO}_{4} \cdot 5 \mathrm{H}_{2} \mathrm{O}(10 \mathrm{~mol} \%)$, was used as catalyst in the presence of sodium ascorbate $(20 \mathrm{~mol} \%)$ and phenylacetylene (1.5 equiv) in toluene $/ \mathrm{H}_{2} \mathrm{O}(3: 1)$ at room temperature; wherein 8 a was obtained in a moderate yield (50\%). An attempt to use copper(I) iodide under the same conditions was made, but again afforded moderate yields, as was the case with copper sulfate. We further examined the effect of solvents on the cycloaddition reaction $\left(1: 3 \mathrm{THF} / \mathrm{H}_{2} \mathrm{O}\right.$, toluene $/ \mathrm{H}_{2} \mathrm{O}, \mathrm{DMF} / \mathrm{H}_{2} \mathrm{O}, \mathrm{CHCl}_{3} / \mathrm{H}_{2} \mathrm{O}$ and $\mathrm{CH}_{2} \mathrm{Cl}_{2}$ ) and the best results were obtained when the reaction was carried out in either $\mathrm{CH}_{2} \mathrm{Cl}_{2}$ or $\mathrm{CHCl}_{3} / \mathrm{H}_{2} \mathrm{O}$ (Scheme 5). Under these conditions, compound 8a was obtained in good yield (90\%).

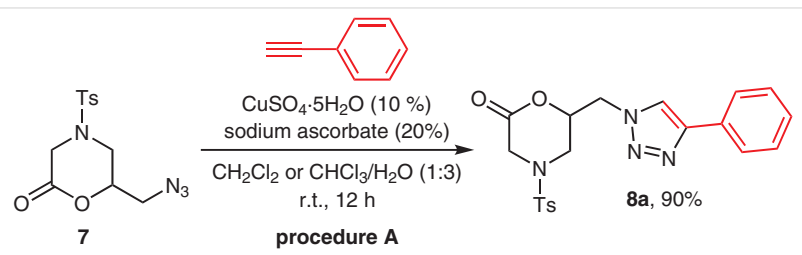

Scheme 5 1,3-Dipolar cycloaddition between 7 and phenylacetylene
Having established that morpholinone $\mathbf{5}$ can be transformed into 1,2,3-triazole derivatives in a two-step procedure, we decided to investigate the 'one-pot' cascade (Scheme 6) of the two previously defined steps (Scheme 4) and we found the presence of 18-crown- 6 to be crucial for the azide substitution reaction to take place. In this context, iodomorpholinone $\mathbf{5}$ was subjected to the copper-catalyzed-multicomponent reaction in the presence of 18 crown-6 using phenylacetylene and sodium azide under the previously defined conditions. As expected, under these conditions (Scheme 6), the multicomponent click reaction worked well and the targeted 1,2,3-triazole 8a was obtained in $82 \%$ yield. It was found that 18 -crown- 6 is indispensable for this three-component reaction. This one-pot reaction led to the isolation of the desired product 8a with a similar yield to the two-step procedure (81\%). To demonstrate the generality of this one-pot morpholinone-triazole synthesis reaction, a range of substituted 1,2,3-triazoles derivatives $\mathbf{8 a}-\mathbf{k}$ were prepared in moderate to excellent yields by using the multicomponent reaction of iodomorpholinone $\mathbf{5}$ and sodium azide with various terminal alkynes.

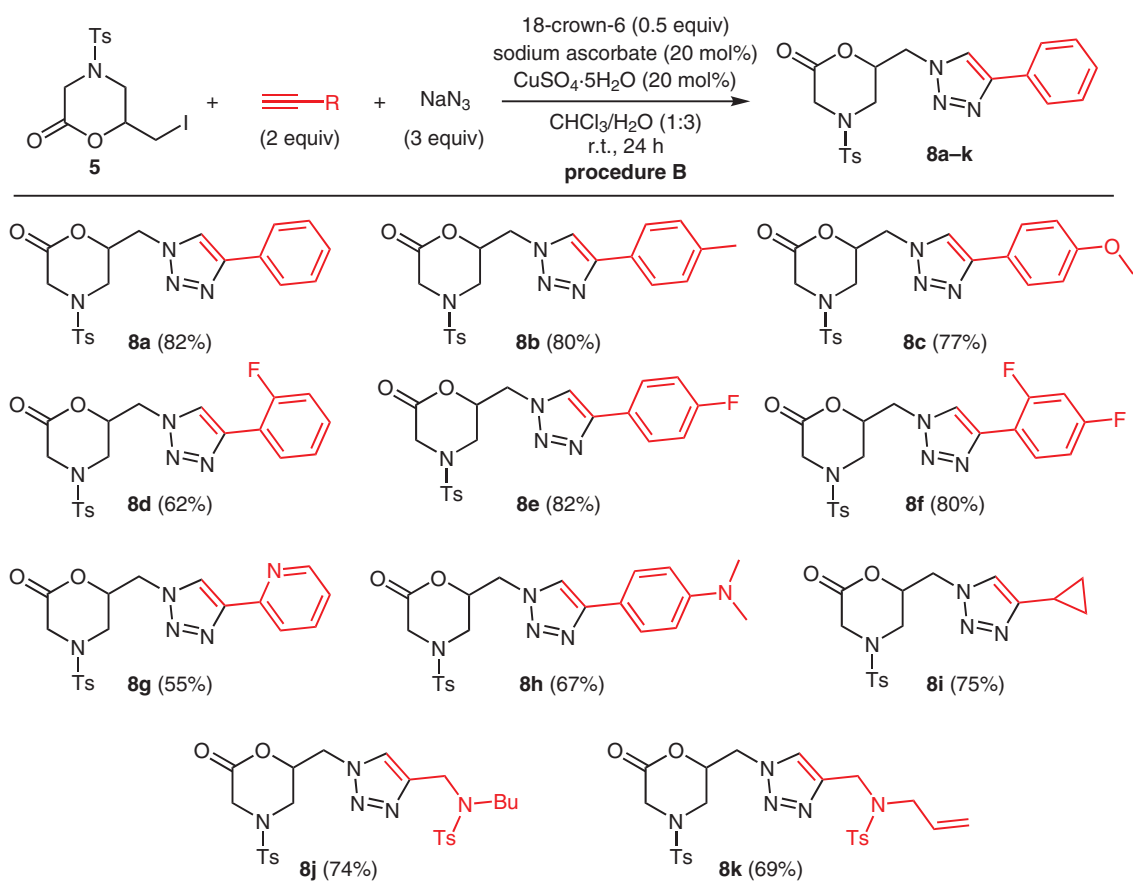

Scheme 6 Synthesis of morpholinone-triazoles 8 through a CuAAC one-pot procedure 
In summary, we have developed an efficient and general methodology for the synthesis of novel six-and sevenmembered iodo heterocycles through electrophilic iodocyclization. We have also demonstrated that the resulting sixmembered iodomorpholinone $\mathbf{5}$ afforded a novel series of heterocyclic derivatives based on morpholinone and triazole heterocycles, prepared using a CuAAC one-pot procedure in the presence of 18-crown-6. Further investigations concerning the scope of applications are ongoing in our laboratory.

All reactions were carried out under an argon atmosphere in dried glassware. THF was distilled under argon from sodium benzophenone ketyl. Dimethylformamide was dried and freshly distilled from calcium hydride. Other chemicals were purchased from Sigma-Aldrich, Alfa Aesar, Fluorochem or ABCR and used without further purification. Reactions were monitored by TLC with Merck silica gel 60 F254. TLC plates were visualized using UV light $(254 \mathrm{~nm})$ or staining with $\mathrm{KMnO}_{4}$. Column chromatography was performed on silica gel (40-63 $\mu \mathrm{m})$ using mixtures of EtOAc and petroleum ether $\left(35-60{ }^{\circ} \mathrm{C}\right.$ fraction) as eluent. ${ }^{1} \mathrm{H}$ NMR spectra were recorded with a Bruker Avance 300 (300 MHz) NMR spectrometer, using as internal deuterium lock the solvents $\mathrm{CDCl}_{3}(\delta 7.26 \mathrm{ppm}),\left(\mathrm{CD}_{3}\right)_{2} \mathrm{CO}(\delta=2.05 \mathrm{ppm})$ or $\left(\mathrm{CD}_{3}\right)_{2} \mathrm{SO}(\delta=$ $2.54 \mathrm{ppm})$. Chemical shifts are quoted in ppm $\left(\delta_{\mathrm{H}}, \delta_{\mathrm{C}}\right)$. Peak multiplicities are defined as: $\mathrm{s}=$ singlet, $\mathrm{d}=$ doublet, $\mathrm{t}=$ triplet, $\mathrm{q}=$ quartet, quint $=$ quintet, sext $=$ sextet, $\mathrm{m}=$ multiplet and $\mathrm{br}=$ broad. Coupling constants $(J)$ are reported in $\mathrm{Hz} .{ }^{13} \mathrm{C}$ NMR spectra were recorded at 75 $\mathrm{MHz}$ on the same instrument, using the solvent peak at as reference $\mathrm{CDCl}_{3}(\delta=77.16 \mathrm{ppm}),\left(\mathrm{CD}_{3}\right)_{2} \mathrm{CO}(\delta=29.85 \mathrm{ppm})$ or $\left(\mathrm{CD}_{3}\right)_{2} \mathrm{SO}(\delta=$ $39.52 \mathrm{ppm}) .{ }^{19} \mathrm{~F}$ NMR spectra were recorded at $282 \mathrm{MHz}$ on the same instrument, using the $\mathrm{CFCl}_{3}$ as the internal reference $(\delta=0.0 \mathrm{ppm})$. Mass spectra were obtained with a Hewlett Packard 5988A by direct inlet at $70 \mathrm{eV}$. HRMS were obtained with a LCMS-IT-TOF mass spectrometer under ESI. Infrared spectra were recorded with a PerkinElmer Spectrum One spectrophotometer with the sample being prepared as a thin film on a diamond ATR module. Absorption maxima $\left(v_{\max }\right)$ are quoted in wavenumbers. Melting points are uncorrected.

\section{Synthesis of 6-(Iodomethyl)-4-tosylmorpholin-2-one (5)}

In a round-bottom flask containing carboxylic acid $\mathbf{2}$ (1 equiv, $300 \mathrm{mg}$, $1.11 \mathrm{mmol})$ and $\mathrm{CHCl}_{3}(25 \mathrm{~mL})$ were added sodium carbonate (2 equiv, $236 \mathrm{mg}, 2.23 \mathrm{mmol}$ ), iodine ( 1.5 equiv, $424 \mathrm{mg}, 1.67 \mathrm{mmol}$ ) and silver nitrate ( 1 equiv, $189 \mathrm{mg}, 1.11 \mathrm{mmol}$ ). The mixture was stirred 2 $h$ at r.t., quenched with a saturated solution of $\mathrm{Na}_{2} \mathrm{~S}_{2} \mathrm{O}_{3}(30 \mathrm{~mL})$ then extracted with dichloromethane $(3 \times 25 \mathrm{~mL})$. The combined organic phases were washed with brine $(3 \times 10 \mathrm{~mL})$, dried over $\mathrm{MgSO}_{4}$, filtered and evaporated under reduced pressure to yield $\mathbf{5}$.

Yield: $258 \mathrm{mg}$ (86\%); yellow solid; $\mathrm{mp} 174-175{ }^{\circ} \mathrm{C} ; R_{f}=0.53$ (EtO$\mathrm{AC} / \mathrm{PE}=1: 4)$.

${ }^{1} \mathrm{H}$ NMR $\left(300 \mathrm{MHz}\right.$, DMSO- $\left.d_{6}\right): \delta=7.68(\mathrm{~d}, J=7.8 \mathrm{~Hz}, 2 \mathrm{H}), 7.40(\mathrm{~d}, J=$ $7.8 \mathrm{~Hz}, 2 \mathrm{H}), 4.52-4.58(\mathrm{~m}, 1 \mathrm{H}), 4.03(\mathrm{~d}, J=17.7 \mathrm{~Hz}, 1 \mathrm{H}), 3.76(\mathrm{~d}, J=$ $12.9 \mathrm{~Hz}, 1 \mathrm{H}), 3.68(\mathrm{~d}, J=17.7 \mathrm{~Hz}, 1 \mathrm{H}), 3.39-3.27(\mathrm{~m}, 2 \mathrm{H}), 3.07$ (dd, $J=7.7,12.9 \mathrm{~Hz}, 1 \mathrm{H}), 2.47(\mathrm{~s}, 3 \mathrm{H})$.

${ }^{13} \mathrm{C}$ NMR (75 MHz, DMSO- $d_{6}$ ): $\delta=163.6,145.26,131.55,130.44$, 127.91, 77.16, 46.79, 46.56, 21.73, 1.74 .

HRMS (ESI): $m / z[M+H]^{+}$calcd for $\mathrm{C}_{12} \mathrm{H}_{15} \mathrm{INO}_{4} \mathrm{~S}$ : 395.97610; found: 395.97568.
Synthesis of 2-(Iodomethyl)-4-tosyl-1,4-oxazepan-7-one (6)

In a round-bottom flask containing carboxylic acid 4 (1 equiv, $300 \mathrm{mg}$, $1.059 \mathrm{mmol})$ and $\mathrm{CHCl}_{3}(25 \mathrm{~mL})$ were added sodium carbonate (2 equiv, $224 \mathrm{mg}, 2.12 \mathrm{mmol}$ ), iodine ( 1.5 equiv, $403 \mathrm{mg}, 1.59 \mathrm{mmol}$ ) and silver nitrate ( 1.5 equiv, $180 \mathrm{mg}, 1.06 \mathrm{mmol}$ ). The mixture was stirred for $2 \mathrm{~h}$ at r.t., quenched with a saturated solution of $\mathrm{Na}_{2} \mathrm{~S}_{2} \mathrm{O}_{3}(30 \mathrm{~mL})$ and extracted with dichloromethane $(3 \times 25 \mathrm{~mL})$. The combined organic phases were washed with brine $(3 \times 10 \mathrm{~mL})$, dried over $\mathrm{MgSO}_{4}$, filtered and evaporated under reduced pressure.

${ }^{1} \mathrm{H}$ NMR $\left(300 \mathrm{MHz}\right.$, DMSO- $\left.d_{6}\right): \delta=7.68(\mathrm{~d}, J=8.17 \mathrm{~Hz}, 2 \mathrm{H}), 7.38(\mathrm{~d}, J=$ $8.17 \mathrm{~Hz}, 2 \mathrm{H}), 4.48-4.54(\mathrm{~m}, 1 \mathrm{H}), 4.24-4.3(\mathrm{dd}, J=1.8 \mathrm{~Hz}, J=14.47 \mathrm{~Hz}$, $1 \mathrm{H}), 4.03-4.11(\mathrm{~m}, 1 \mathrm{H}), 3.28-3.41(\mathrm{~m}, 2 \mathrm{H}), 2.71-3.04(\mathrm{~m}, 4 \mathrm{H}), 2.47$ ( $\mathrm{s}, 3 \mathrm{H})$.

${ }^{13} \mathrm{C}$ NMR $\left(75 \mathrm{MHz}\right.$, DMSO- $\left.d_{6}\right): \delta=163.51,145.21,131.39,130.35$, $127.81,77.27,53.57,46.71,46.48,21.6,1.76$.

HRMS (ESI): $m / z[M+\mathrm{H}]^{+}$calcd for $\mathrm{C}_{13} \mathrm{H}_{17} \mathrm{INO}_{4} \mathrm{~S}: 409.99175$; found: 409.99147.

\section{Synthesis of 6-(Azidomethyl)-4 tosylmorpholin-2-one (7)}

A mixture of the appropriate 6-(iodomethyl)-4-tosylmorpholin-2one 5 (300 mg, $0.76 \mathrm{mmol}$ ), sodium azide (148 mg, $2.28 \mathrm{mmol}$ ), 18crown-6 (100 mg, $0.38 \mathrm{mmol})$ and acetone $(20 \mathrm{~mL})$ was stirred at r.t. until completion of the reaction (TLC). The solvents were evaporated under reduced pressure, and the crude product was then poured into water, extracted with $\mathrm{CH}_{2} \mathrm{Cl}_{2}(3 \times 40 \mathrm{~mL})$, dried $\left(\mathrm{MgSO}_{4}\right)$, filtered and concentrated under reduced pressure. The crude product was purified by silica gel chromatography using PE/EtOAc (6:1) mixture as eluent.

${ }^{1} \mathrm{H}$ NMR $\left(300 \mathrm{MHz}, \mathrm{CDCl}_{3}\right): \delta=7.67(\mathrm{~d}, J=8.3 \mathrm{~Hz}, 2 \mathrm{H}), 7.40(\mathrm{~d}, J=$ $8.3 \mathrm{~Hz}, 2 \mathrm{H}), 4.68-4.61(\mathrm{~m}, 1 \mathrm{H}), 4.11(\mathrm{dd}, J=1.1,17.6 \mathrm{~Hz}, 1 \mathrm{H}), 3.67-$ $3.58(\mathrm{~m}, 3 \mathrm{H}), 3.53(\mathrm{dd}, J=4.4,13.2 \mathrm{~Hz}), 2.94(\mathrm{dd}, J=8.6,12.7 \mathrm{~Hz}, 1 \mathrm{H})$, $2.47(\mathrm{~s}, 3 \mathrm{H})$.

${ }^{13} \mathrm{C}$ NMR $\left(75 \mathrm{MHz}, \mathrm{CDCl}_{3}\right): \delta=163.52,145.29,131.34,130.43,130.28$, 127.91, 76.77, 51.68, 46.97, 44.25, 21.71.

HRMS (ESI): $m / z$ [M + H] $]^{+}$calcd for $\mathrm{C}_{12} \mathrm{H}_{15} \mathrm{IN}_{4} \mathrm{O}_{4} \mathrm{~S}: 311.08085$; found: 311.08011.

\section{Synthesis of Triazoles; General Procedures}

\section{Method A}

Finely powdered $\mathrm{CuSO}_{4} \cdot 5 \mathrm{H}_{2} \mathrm{O}(16 \mathrm{mg}, 10 \mathrm{~mol} \%)$ and sodium ascorbate ( $26 \mathrm{mg}, 20 \mathrm{~mol} \%$ ) were slowly added to a stirred solution of 6-(azidomethyl)-4-tosylmorpholin-2-one 7 (200 mg, $0.64 \mathrm{mmol})$ and terminal alkyne ( $0.96 \mathrm{mmol}, 1.5$ equiv) in $\mathrm{H}_{2} \mathrm{O} / \mathrm{CHCl}_{3}(3: 1=15 \mathrm{~mL} / 5 \mathrm{~mL})$ at $0-10{ }^{\circ} \mathrm{C}$. The mixture was then allowed to reach r.t. and TLC monitoring was used to follow reaction progress. The mixture was filtered, concentrated and diluted with water $(30 \mathrm{~mL})$. The aqueous layer was extracted with $\mathrm{CHCl}_{3}(3 \times 20 \mathrm{~mL})$, the combined organic layers were washed with $\mathrm{H}_{2} \mathrm{O}$ and then with brine, dried over $\mathrm{Na}_{2} \mathrm{SO}_{4}$, filtered and concentrated under vacuum. The crude products were crystallized from various solvents or purified by flash chromatography over silica gel (eluent $\mathrm{CHCl}_{3} / \mathrm{MeOH}=88: 12$ ) to afford the desired pure triazole product.

\section{Method B}

6-(Iodomethyl)-4-tosylmorpholin-2-one $\mathbf{5}$ (789 mg, $2 \mathrm{mmol}$ ) was dissolved in $\mathrm{H}_{2} \mathrm{O} / \mathrm{CHCl}_{3}(3: 1=22.5 \mathrm{~mL} / 7.5 \mathrm{~mL})$. Sodium azide $(390 \mathrm{mg}, 6$ $\mathrm{mmol}$ ) and 18 -crown-6 (264 mg, $1 \mathrm{mmol}$ ) were then added to the solution and the suspension was stirred for $30 \mathrm{~min}$. The mixture was degassed at $0{ }^{\circ} \mathrm{C}$, then the terminal alkyne ( $4.0 \mathrm{mmol}, 2$ equiv), sodi- 
um ascorbate ( $79 \mathrm{mg}, 0.4 \mathrm{mmol}, 0.2$ equiv) and $\mathrm{CuSO}_{4} \cdot 5 \mathrm{H}_{2} \mathrm{O}(100 \mathrm{mg}$, $0.4 \mathrm{mmol}, 0.2$ equiv) were added to the mixture which was then stirred for $24 \mathrm{~h}$. The reaction was quenched by the addition of saturated aqueous $\mathrm{NH}_{4} \mathrm{Cl}(20 \mathrm{~mL})$ and the mixture was stirred for a further $15 \mathrm{~min}$. The mixture was filtered through a pad of Celite ${ }^{\circledR}$ and the filtrate was extracted with EtOAc $(3 \times 40 \mathrm{~mL})$. The combined organic layers were washed with brine, dried over $\mathrm{Na}_{2} \mathrm{SO}_{4}$, filtered and concentrated under reduced pressure. The crude product was then purified by recrystallization or by flash chromatography on silica gel using PE/EtOAC as the eluent.

\section{6-[(4-Phenyl-1H-1,2,3-triazol-1-yl)methyl]-4-tosylmorpholin-2- one (8a)}

According to general procedure B, compound 8a was isolated after recrystallization (EtOH).

Yield: $675 \mathrm{mg}$ (82\%); white solid; $\mathrm{mp} 213-214{ }^{\circ} \mathrm{C} ; R_{f}=0.35$ (EtOAC/PE $=4: 1$ ).

${ }^{1} \mathrm{H}$ NMR (300 MHz, DMSO- $\left.d_{6}\right): \delta=8.54(\mathrm{~s}, 1 \mathrm{H}), 7.83(\mathrm{~d}, J=7.75 \mathrm{~Hz}$, $2 \mathrm{H}), 7.69$ (d, $J=7.75 \mathrm{~Hz}, 2 \mathrm{H}), 7.45(\mathrm{~m}, 4 \mathrm{H}), 7.34(\mathrm{t}, J=7.3 \mathrm{~Hz}, 1 \mathrm{H})$, $5.00-5.05(\mathrm{~m}, 1 \mathrm{H}), 4.80(\mathrm{dd}, J=3.5,14.6 \mathrm{~Hz}, 1 \mathrm{H}), 4.72(\mathrm{dd}, J=7.3$, $14.6 \mathrm{~Hz}, 1 \mathrm{H}), 4.03(\mathrm{~d}, J=17.2 \mathrm{~Hz}, 1 \mathrm{H}), 3.77(\mathrm{dd}, J=3.0,12.3 \mathrm{~Hz}, 1 \mathrm{H})$, $3.73(\mathrm{~d}, J=17.2 \mathrm{~Hz}, 1 \mathrm{H}$ ), 3.07 (dd, $J=8.9,12.5 \mathrm{~Hz}, 1 \mathrm{H}$ ), 2.38 (s, $3 \mathrm{H}$ ).

${ }^{13} \mathrm{C}$ NMR (75 MHz, DMSO- $d_{6}$ ): $\delta=164.21,146.39,144.46,131.71$, 130.54, 130.21, 128.98, 128.01, 127.71, 125.2, 122.42, 75.75, 50.71, 46.49, 43.53, 21.04.

HRMS (ESI): $m / z[M+H]^{+}$calcd for $\mathrm{C}_{20} \mathrm{H}_{21} \mathrm{~N}_{4} \mathrm{O}_{4} \mathrm{~S}: 413.12780$; found: 431.12656.

6-\{[4-(p-Tolyl)-1H-1,2,3-triazol-1-yl]methyl\}-4-tosylmorpholin-2one (8b)

According to general procedure B, compound $\mathbf{8 b}$ was isolated after recrystallization (EtOH).

Yield: $681 \mathrm{mg}$ (80\%); white solid; $\mathrm{mp} 191-192{ }^{\circ} \mathrm{C} ; R_{f}=0.38$ (EtOAC/PE $=4: 1$ ).

${ }^{1} \mathrm{H}$ NMR (300 MHz, DMSO- $\left.d_{6}\right): \delta=8.47(\mathrm{~s}, 1 \mathrm{H}), 7.72(\mathrm{~d}, J=6.4 \mathrm{~Hz}$, $2 \mathrm{H}), 7.69(\mathrm{~d}, J=6.4 \mathrm{~Hz}, 2 \mathrm{H}), 7.45(\mathrm{~d}, J=8.1 \mathrm{~Hz}, 2 \mathrm{H}), 7.26(\mathrm{~d}, J=$ $8.1 \mathrm{~Hz}, 2 \mathrm{H}), 5.03-4.98(\mathrm{~m}, 1 \mathrm{H}), 4.02(\mathrm{~d}, J=18.1 \mathrm{~Hz}, 1 \mathrm{H}), 3.76(\mathrm{dd}, J=$ 3.5, $11.7 \mathrm{~Hz}, 1 \mathrm{H}$ ), 3.75 (d, $J=18.1 \mathrm{~Hz}, 1 \mathrm{H}), 3.06$ (dd, $J=8.9,12.5 \mathrm{~Hz}$, $1 \mathrm{H}), 2.38(\mathrm{~s}, 3 \mathrm{H}), 2.32(\mathrm{~s}, 3 \mathrm{H})$.

${ }^{13} \mathrm{C}$ NMR (75 MHz, DMSO- $\left.d_{6}\right): \delta=164.28,145.52,137.41,131.75$, $130.28,129.58,127.8,127.77,125.2,122.04,75.82,50.73,46.53$, 43.59, 21.1, 20.91 .

HRMS (ESI): $m / z[M+H]^{+}$calcd for $\mathrm{C}_{21} \mathrm{H}_{23} \mathrm{~N}_{4} \mathrm{O}_{4} \mathrm{~S}: 427.14345$; found: 427.14241.

\section{6-\{[4-(4-Methoxyphenyl)-1H-1,2,3-triazol-1-yl]methyl\}-4-to-} sylmorpholin-2-one (8c)

According to general procedure B, compound $\mathbf{8 c}$ was isolated after recrystallization (EtOH).

Yield: $680 \mathrm{mg}$ (77\%); white solid; $\mathrm{mp} 225-226^{\circ} \mathrm{C} ; R_{\mathrm{f}}=0.37$ (EtOAc/PE $=4: 1$ ).

${ }^{1} \mathrm{H}$ NMR $\left(300 \mathrm{MHz}\right.$, DMSO- $\left.d_{6}\right): \delta=8.42(\mathrm{~s}, 1 \mathrm{H}), 7.75(\mathrm{~d}, J=8.8 \mathrm{~Hz}$, $2 \mathrm{H}), 7.69$ (d, $J=8.2 \mathrm{~Hz}, 2 \mathrm{H}), 7.46(\mathrm{~d}, J=8.2 \mathrm{~Hz}, 2 \mathrm{H}), 7.02$ (d, $J=$ $8.8 \mathrm{~Hz}, 2 \mathrm{H}$ ), 5.04-4.96 (m, $1 \mathrm{H}), 4.77$ (dd, $J=3.9,14.5 \mathrm{~Hz}, 1 \mathrm{H}), 4.69$ (dd, $J=7.4,14.5 \mathrm{~Hz}, 1 \mathrm{H}), 4.03(\mathrm{~d}, J=17.1 \mathrm{~Hz}, 1 \mathrm{H}), 3.78(\mathrm{~s}, 3 \mathrm{H}), 3.77$ (dd, $J=3.2,12.4 \mathrm{~Hz}, 1 \mathrm{H}), 3.75(\mathrm{~d}, J=17.1 \mathrm{~Hz}, 1 \mathrm{H}), 3.06$ (dd, $J=9.0$, $12.6 \mathrm{~Hz}, 1 \mathrm{H}), 2.39$ (s, $3 \mathrm{H})$.
${ }^{13} \mathrm{C}$ NMR (75 MHz, DMSO- $d_{6}$ ): $\delta=164.29,159.15,146.39,144.54$, 131.74, 130.28, 127.76, 126.62, 123.15, 121.5, 114.43, 75.82, 55.23, 50.7, 46.52, 43.59, 21.1 .

HRMS (ESI): $m / z[\mathrm{M}+\mathrm{H}]^{+}$calcd for $\mathrm{C}_{21} \mathrm{H}_{23} \mathrm{~N}_{4} \mathrm{O}_{5} \mathrm{~S}: 443.13837$; found: 443.13705 .

\section{6-\{[4-(2-Fluorophenyl)-1H-1,2,3-triazol-1-yl]methyl\}-4-tosylmor-} pholin-2-one (8d)

According to general procedure B, compound $\mathbf{8 d}$ was isolated after recrystallization (EtOH).

Yield: $533 \mathrm{mg}$ (62\%); white solid; $\mathrm{mp} 191-192{ }^{\circ} \mathrm{C} ; R_{f}=0.38$ (EtOAc/PE $=4: 1$ ).

${ }^{1} \mathrm{H}$ NMR $\left(300 \mathrm{MHz}\right.$, DMSO- $\left.d_{6}\right): \delta=8.45(\mathrm{~d}, J=3.81 \mathrm{~Hz}, 1 \mathrm{H}), 8.15(\mathrm{td}$, $J=1.7,7.4 \mathrm{~Hz}, 1 \mathrm{H}), 7.17$ (d, $J=8.15 \mathrm{~Hz}, 2 \mathrm{H}), 7.47(\mathrm{~d}, J=8.15 \mathrm{~Hz}, 2 \mathrm{H})$, 7.42-7.31 (m, $3 \mathrm{H}), 5.08-5.00(\mathrm{~m}, 1 \mathrm{H}), 4.87-4.74(\mathrm{~m}, 2 \mathrm{H}), 4.01(\mathrm{~d}, J=$ $17.0 \mathrm{~Hz}, 1 \mathrm{H}), 3.78(\mathrm{~d}, J=17.0 \mathrm{~Hz}, 1 \mathrm{H}), 3.73(\mathrm{dd}, J=3.3,12.3 \mathrm{~Hz}, 1 \mathrm{H})$, $3.10(\mathrm{dd}, J=8.4,12.6 \mathrm{~Hz}, 1 \mathrm{H}), 2.39(\mathrm{~s}, 3 \mathrm{H})$.

${ }^{13} \mathrm{C}$ NMR $\left(75 \mathrm{MHz}\right.$, DMSO- $\left.d_{6}\right): \delta=164.14,158.46(\mathrm{~d}, J=247 \mathrm{~Hz})$, $144.42,139.72(\mathrm{~d}, J=2.3 \mathrm{~Hz}), 131.70,130.18,127.27(\mathrm{~d}, J=3.4 \mathrm{~Hz})$, $125.0(\mathrm{~d}, J=3.15 \mathrm{~Hz}), 124.77(\mathrm{~d}, J=11.7 \mathrm{~Hz}), 118.21(\mathrm{~d}, J=21.3 \mathrm{~Hz})$, 116.05 (d, $J=21.3 \mathrm{~Hz}$ ), 75.80, 50.71, 46.52, 43.49, 21.01.

${ }^{19} \mathrm{~F}$ NMR $\left(282 \mathrm{MHz}\right.$, DMSO- $\left.d_{6}\right): \delta=-114.65$.

HRMS (ESI): $m / z[\mathrm{M}+\mathrm{H}]^{+}$calcd for $\mathrm{C}_{20} \mathrm{H}_{20} \mathrm{FN}_{4} \mathrm{O}_{4} \mathrm{~S}$ : 431.11893 ; found: 431.11709 .

6-\{[4-(4-Fluorophenyl)-1H-1,2,3-triazol-1-yl]methyl\}-4-tosylmorpholin-2-one (8e)

According to general procedure $\mathrm{B}$, compound $\mathbf{8 e}$ was isolated after recrystallization (EtOH).

Yield: $705 \mathrm{mg}$ (82\%); white solid; $\mathrm{mp} 207-208^{\circ} \mathrm{C} ; R_{f}=0.38$ (EtOAc/PE $=4: 1$ ).

${ }^{1} \mathrm{H}$ NMR (300 MHz, DMSO- $\left.d_{6}\right): \delta=8.53(\mathrm{~s}, 1 \mathrm{H}), 7.87(\mathrm{dd}, J=5.5$, $8.8 \mathrm{~Hz}, 2 \mathrm{H}), 7.70$ (d, J = 8.2 Hz, $2 \mathrm{H}$ ), 7.46 (d, J = 8.2 Hz, $2 \mathrm{H}), 7.30$ (t, $J=8.9 \mathrm{~Hz}, 2 \mathrm{H}), 5.00-5.05(\mathrm{~m}, 1 \mathrm{H}), 4.80(\mathrm{dd}, J=3.8,14.6 \mathrm{~Hz}, 1 \mathrm{H}), 4.71$ (dd, $J=7.3,14.6 \mathrm{~Hz}, 1 \mathrm{H}), 4.03(\mathrm{~d}, J=17.15 \mathrm{~Hz}, 1 \mathrm{H}), 3.77$ (dd, $J=3.1$, $12.8 \mathrm{~Hz}, 1 \mathrm{H}$ ), 3.76 (d, $J=17.15 \mathrm{~Hz}, 1 \mathrm{H}$ ), $3.04(\mathrm{dd}, J=8.8,12.7 \mathrm{~Hz}, 1 \mathrm{H}$ ), $2.38(\mathrm{~s}, 3 \mathrm{H})$

${ }^{13} \mathrm{C}$ NMR (75 MHz, DMSO- $d_{6}$ ): $\delta=164.33,161.95(\mathrm{~d}, J=244.5 \mathrm{~Hz}$ ), 145.65, 144.6, 131.76, 130.32, 127.8, 127.43, 127.35 (d, $J=8.2 \mathrm{~Hz}$ ), $127.17(\mathrm{~d}, J=3.1 \mathrm{~Hz}), 122.44,116.02(\mathrm{~d}, J=22 \mathrm{~Hz}), 75.83,50.82,46.56$, 43.61, 21.13.

${ }^{19} \mathrm{~F}$ NMR $\left(282 \mathrm{MHz}\right.$, DMSO- $\left.d_{6}\right): \delta=-113.84$.

HRMS (ESI): $m / z[\mathrm{M}+\mathrm{H}]^{+}$calcd for $\mathrm{C}_{2} \mathrm{H}_{20} \mathrm{FN}_{4} \mathrm{O}_{4} \mathrm{~S}$ : 431.11838; found: 431.11736.

\section{6-\{[4-(2,4-Difluorophenyl)-1H-1,2,3-triazol-1-yl]methyl\}-4-to-} sylmorpholin-2-one (8f)

According to general procedure B, compound $\mathbf{8 f}$ was isolated after recrystallization (EtOH).

Yield: $716 \mathrm{mg}$ (80\%); white solid; $\mathrm{mp} 213-214^{\circ} \mathrm{C} ; R_{f}=0.35$ (EtOAc/PE $=4: 1)$.

${ }^{1} \mathrm{H} \mathrm{NMR}\left(300 \mathrm{MHz}\right.$, DMSO- $\left.d_{6}\right): \delta=8.44(\mathrm{~d}, J=3.55 \mathrm{~Hz}, 1 \mathrm{H}), 8.20-8.12$ $(\mathrm{m}, 1 \mathrm{H}), 7.70$ (d, $J=7.8 \mathrm{~Hz}, 2 \mathrm{H}), 7.46(\mathrm{~d}, J=7.8 \mathrm{~Hz}, 2 \mathrm{H}), 7.43-7.37$ (m, $1 \mathrm{H}), 7.27-7.20(\mathrm{~m}, 1 \mathrm{H}), 5.06-5.00(\mathrm{~m}, 1 \mathrm{H}), 4.84-4.76(\mathrm{~m}, 2 \mathrm{H})$, $4.00(\mathrm{~d}, J=10.1 \mathrm{~Hz}, 1 \mathrm{H}), 3.77(\mathrm{~d}, J=17.1 \mathrm{~Hz}, 1 \mathrm{H}), 3.73(\mathrm{dd}, J=2.8$, $12.05 \mathrm{~Hz}, 1 \mathrm{H}), 3.10$ (dd, J = 8.5, $12.6 \mathrm{~Hz}, 1 \mathrm{H}), 2.39$ (s, $3 \mathrm{H}$ ). 
${ }^{13} \mathrm{C}$ NMR (75 MHz, DMSO- $d_{6}$ ): $\delta=164.1,161.78$ (dd, $J=12.5$, $247.3 \mathrm{~Hz}$ ), 158.49 (dd, $J=12.7,248.6 \mathrm{~Hz}), 144.41,139.12$ (d, $J=$ $2.2 \mathrm{~Hz}$ ), 131.70, 130.15, 128.50 (dd, $J=5.2,9.7 \mathrm{~Hz}$ ), 127.68, 124.41 (d, $J=11.1 \mathrm{~Hz}), 115.03(\mathrm{dd}, J=3.75,13.4 \mathrm{~Hz}), 112.30(\mathrm{dd}, J=3.25$, $21.3 \mathrm{~Hz}), 104.56$ (t, $J=26 \mathrm{~Hz}), 75.79,50.74,46.51,43.48,20.99$.

${ }^{19} \mathrm{~F}$ NMR $\left(282 \mathrm{MHz}\right.$, DMSO- $\left.d_{6}\right): \delta=-110.56(\mathrm{~d}, J=7.7 \mathrm{~Hz}),-110.35(\mathrm{~d}$, $J=7.7 \mathrm{~Hz}$.

HRMS (ESI): $m / z$ [M $+\mathrm{H}]^{+}$calcd for $\mathrm{C}_{21} \mathrm{H}_{22} \mathrm{~N}_{4} \mathrm{O}_{4} \mathrm{~S}$ : 449.10896; found: 449.10778 .

\section{6-\{[4-(Pyridin-2-yl)-1H-1,2,3-triazol-1-yl]methyl\}-4-tosylmor- pholin-2-one (8g)}

According to general procedure B, compound $\mathbf{8 g}$ was isolated after recrystallization (EtOH).

Yield: $454 \mathrm{mg}$ (55\%); white solid; $\mathrm{mp} 225-226^{\circ} \mathrm{C} ; R_{f}=0.37$ (EtOAc/PE $=4: 1$ ).

${ }^{1} \mathrm{H}$ NMR $\left(300 \mathrm{MHz}\right.$, DMSO- $\left.d_{6}\right): \delta=8.65-8.59(\mathrm{~m}, 2 \mathrm{H}), 8.05(\mathrm{~d}, J=$ $7.6 \mathrm{~Hz}, 1 \mathrm{H}), 7.91(\mathrm{t}, J=7.2 \mathrm{~Hz}, 1 \mathrm{H}), 7.71(\mathrm{~d}, J=8.1 \mathrm{~Hz}, 2 \mathrm{H}), 7.47(\mathrm{~d}, J=$ $8.1 \mathrm{~Hz}, 2 \mathrm{H}), 7.39-7.35(\mathrm{~m}, 1 \mathrm{H}), 5.06-5.00(\mathrm{~m}, 1 \mathrm{H}), 4.87-4.74(\mathrm{~m}$, $2 \mathrm{H}), 4.02(\mathrm{~d}, J=17.1 \mathrm{~Hz}, 1 \mathrm{H}), 3.79(\mathrm{~d}, J=17.1 \mathrm{~Hz}, 1 \mathrm{H}), 3.75(\mathrm{dd}, J=$ 3.1, $12.5 \mathrm{~Hz}, 1 \mathrm{H}), 3.11(\mathrm{dd}, J=8.6,12.5 \mathrm{~Hz}, 1 \mathrm{H}), 2.39(\mathrm{~s}, 3 \mathrm{H})$.

${ }^{13} \mathrm{C}$ NMR $\left(75 \mathrm{MHz}\right.$, DMSO- $\left.d_{6}\right): \delta=175.38,155.16,148.33,145.94$, $141.92,141.82,137.66,134.85,132.63,132.17,128.94,124.34,88.25$, $85.08,55.78,52.53,26.13$.

HRMS (ESI): $m / z[\mathrm{M}+\mathrm{H}]^{+}$calcd for $\mathrm{C}_{19} \mathrm{H}_{20} \mathrm{~N}_{5} \mathrm{O}_{4} \mathrm{~S}: 414.12305$; found: 414.12213

\section{6-[\{4-[4-(Dimethylamino)phenyl]-1H-1,2,3-triazol-1-yl $\}$ methyl]- 4-tosylmorpholin-2-one (8h)}

According to general procedure B, compound $\mathbf{8 h}$ was isolated after recrystallization (EtOH).

Yield: $609 \mathrm{mg}$ (67\%); white solid; $\mathrm{mp} 237-238^{\circ} \mathrm{C} ; R_{f}=0.35$ (EtOAc/PE $=4: 1$ ).

${ }^{1} \mathrm{H}$ NMR $\left(300 \mathrm{MHz}\right.$, DMSO- $\left.d_{6}\right): \delta=8.32(\mathrm{~s}, 1 \mathrm{H}), 7.70(\mathrm{~d}, J=8.2 \mathrm{~Hz}$, $2 \mathrm{H}), 7.64(\mathrm{~d}, J=8.7 \mathrm{~Hz}, 2 \mathrm{H}), 7.46(\mathrm{~d}, J=8.2 \mathrm{~Hz}, 2 \mathrm{H}), 6.78(\mathrm{~d}, J=$ $8.7 \mathrm{~Hz}, 2 \mathrm{H}$ ), 5.05-4.97 (m, $1 \mathrm{H}), 4.74$ (dd, $J=3.8,14.6 \mathrm{~Hz}, 1 \mathrm{H}), 4.67$ $(\mathrm{dd}, J=7.3,14.6 \mathrm{~Hz}), 4.04(\mathrm{~d}, J=17.1 \mathrm{~Hz}, 1 \mathrm{H}), 3.77(\mathrm{dd}, J=8.9$, $12.6 \mathrm{~Hz}, 1 \mathrm{H}$ ), 3.75 (d, $J=17.1 \mathrm{~Hz}, 1 \mathrm{H}), 3.06(\mathrm{dd}, J=8.9,12.6 \mathrm{~Hz}, 1 \mathrm{H}$ ), $2.93(\mathrm{~s}, 6 \mathrm{H}), 2.39$ (s, $3 \mathrm{H})$

${ }^{13} \mathrm{C}$ NMR $\left(75 \mathrm{MHz}\right.$, DMSO- $\left.d_{6}\right): \delta=164.22,150.09,147.02,144.44$, $131.73,130.2,127.7,126.1,120.47,118.4,112.36,75.81,50.56,46.47$, $43.56,21.04$

HRMS (ESI): $m / z[M+\mathrm{H}]^{+}$calcd for $\mathrm{C}_{22} \mathrm{H}_{26} \mathrm{~N}_{5} \mathrm{O}_{4} \mathrm{~S}: 456.17000$; found: 456.16862 .

\section{6-[(4-Cyclopropyl-1H-1,2,3-triazol-1-yl)methyl]-4-tosylmor- pholin-2-one (8i)}

According to general procedure B, compound $\mathbf{8 i}$ was isolated after recrystallization (EtOH).

Yield: $564 \mathrm{mg}$ (75\%); white solid; $\mathrm{mp} 177-178^{\circ} \mathrm{C} ; R_{f}=0.35$ (EtOAc $/ \mathrm{PE}$ $=4: 1$.

${ }^{1} \mathrm{H}$ NMR $\left(300 \mathrm{MHz}\right.$, DMSO- $\left.d_{6}\right): \delta=7.80(\mathrm{~s}, 1 \mathrm{H}), 7.70(\mathrm{~d}, J=8.2 \mathrm{~Hz}$, $2 \mathrm{H}), 7.48(\mathrm{~d}, J=8.2 \mathrm{~Hz}, 2 \mathrm{H}), 4.95-4.88(\mathrm{~m}, 1 \mathrm{H}), 4.65(\mathrm{dd}, J=3.9$, $14.6 \mathrm{~Hz}, 1 \mathrm{H}), 4.57(\mathrm{dd}, J=7.5,14.6 \mathrm{~Hz}, 1 \mathrm{H}), 4.01(\mathrm{~d}, J=17.1 \mathrm{~Hz}, 1 \mathrm{H})$, $3.72(\mathrm{~d}, J=17.1 \mathrm{~Hz}, 1 \mathrm{H}), 3.70(\mathrm{dd}, J=3.2,12.6 \mathrm{~Hz}, 1 \mathrm{H}), 3.00(\mathrm{dd}, J=$ $8.8,12.6 \mathrm{~Hz}, 1 \mathrm{H}), 2.42(\mathrm{~s}, 3 \mathrm{H}), 1.98-1.88(\mathrm{~m}, 1 \mathrm{H}), 0.92-0.86(\mathrm{~m}, 2 \mathrm{H})$, $0.72-0.67(\mathrm{~m}, 2 \mathrm{H})$.
${ }^{13} \mathrm{C}$ NMR $\left(75 \mathrm{MHz}\right.$, DMSO- $\left.d_{6}\right): \delta=164.16,148.91,144.45,131.71$, 130.2, 127.7, 121.78, 75.85, 69.69, 50.4, 46.45, 43.53, 21.06, 7.61, 6.44. HRMS $\left(\mathrm{ESI}^{+}\right): \mathrm{m} / z[\mathrm{M}+\mathrm{H}]^{+}$calcd for $\mathrm{C}_{17} \mathrm{H}_{21} \mathrm{~N}_{4} \mathrm{O}_{4} \mathrm{~S}$ : 377.12830; found: 377.12731 .

$N$-Butyl-4-methyl- $N$-(\{1-[(6-oxo-4-tosylmorpholin-2-yl)methyl]1H-1,2,3-triazol-4-yl\}methyl)benzenesulfonamide (8j)

According to general procedure $\mathrm{B}$, compound $\mathbf{8 j}$ was isolated after recrystallization (EtOH).

Yield: $851 \mathrm{mg}$ (74\%); white solid; $\mathrm{mp} 179-180{ }^{\circ} \mathrm{C} ; R_{f}=0.33$ (EtOAc/PE $=4: 1$ ).

${ }^{1} \mathrm{H}$ NMR $\left(300 \mathrm{MHz}\right.$, DMSO- $\left.d_{6}\right): \delta=7.95(\mathrm{~s}, 1 \mathrm{H}), 7.71(\mathrm{~d}, J=8.2 \mathrm{~Hz}$, $2 \mathrm{H}), 7.66(\mathrm{~d}, J=8.2 \mathrm{~Hz}, 2 \mathrm{H}), 7.48(\mathrm{~d}, J=8.1 \mathrm{~Hz}, 2 \mathrm{H}), 7.37(\mathrm{~d}, J=$ $8.1 \mathrm{~Hz}, 2 \mathrm{H}), 4.93-4.87(\mathrm{~m}, 1 \mathrm{H}), 4.73-4.61(\mathrm{~m}, 2 \mathrm{H}), 4.37(\mathrm{~s}, 2 \mathrm{H}), 4.03$ $(\mathrm{d}, J=17.2 \mathrm{~Hz}, 1 \mathrm{H}), 3.72(\mathrm{dd}, J=2.9,12.4 \mathrm{~Hz}, 1 \mathrm{H}), 3.71(\mathrm{~d}, J=17.2 \mathrm{~Hz}$, $1 \mathrm{H}), 2.95-3.07$ (m, $3 \mathrm{H}), 2.42$ (s, $3 \mathrm{H}), 2.38$ (s, $3 \mathrm{H}), 1.40-1.30(\mathrm{~m}, 2 \mathrm{H})$, $1.15-1.07(\mathrm{~m}, 2 \mathrm{H}), 0.74(\mathrm{t}, J=7.27 \mathrm{~Hz}, 3 \mathrm{H})$.

${ }^{13} \mathrm{C}$ NMR $\left(75 \mathrm{MHz}\right.$, DMSO- $\left.d_{6}\right): \delta=163.98,144.48,143.08,142.94$, 136.29, 131.7, 130.21, 129.72, 127.68, 126.93, 124.89, 75.91, 50.54, 47.32, 46.84, 43.52, 42.33, 29.54, 21.04, 20.94, 19.05, 13.39 .

HRMS (ESI): $m / z[M+H]^{+}$calcd for $\mathrm{C}_{26} \mathrm{H}_{34} \mathrm{~N}_{5} \mathrm{O}_{6} \mathrm{~S}_{2}$ : 576.19450; found: 576.19292.

$N$-Allyl-4-methyl- $N$-\{1-[(6-oxo-4-tosylmorpholin-2-yl)methyl]1H-1,2,3-triazol-4-yl\}benzenesulfonamide (8k)

According to general procedure B, compound 8k was isolated after flash chromatography.

Yield: $771 \mathrm{mg}$ (69\%); white solid; $\mathrm{mp} 157-158^{\circ} \mathrm{C} ; R_{\mathrm{f}}=0.35$ (EtOAc/PE $=4: 1$ ).

${ }^{1} \mathrm{H}$ NMR $\left(300 \mathrm{MHz}\right.$, acetone- $\left.d_{6}\right): \delta=7.83(\mathrm{~s}, 1 \mathrm{H}), 7.72(\mathrm{~d}, J=8.0 \mathrm{~Hz}$, $2 \mathrm{H}), 7.69(\mathrm{~d}, J=8.0 \mathrm{~Hz}, 2 \mathrm{H}), 7.48(\mathrm{~d}, J=8.4 \mathrm{~Hz}, 2 \mathrm{H}), 7.37(\mathrm{~d}, J=$ $8.4 \mathrm{~Hz}, 2 \mathrm{H}$ ), 5.60 (ddt, $J=6.3,10.2,17.1 \mathrm{~Hz}, 1 \mathrm{H}), 5.15$ (dq, $J=1.5$, $17.1 \mathrm{~Hz}, 1 \mathrm{H}), 5.05$ (dq, $J=1.6,10.2 \mathrm{~Hz}, 1 \mathrm{H}), 5.03-4.96(\mathrm{~m}, 1 \mathrm{H}), 4.84-$ $4.71(\mathrm{~m}, 2 \mathrm{H}), 4.43(\mathrm{~s}, 2 \mathrm{H}), 4.03(\mathrm{~d}, J=17.3 \mathrm{~Hz}, 2 \mathrm{H}), 3.84-3.76(\mathrm{~m}$, $2 \mathrm{H}$ ), 3.10 (dd, $J=8.3,12.8 \mathrm{~Hz}, 2 \mathrm{H}$ ), 2.42 (s, $3 \mathrm{H}$ ), 2.39 (s, $3 \mathrm{H}$ ).

${ }^{13} \mathrm{C}$ NMR (75 MHz, acetone- $d_{6}$ ): $\delta=164.27,145.67,144.29,138.44$, 133.51, 131.1, 130.62, 128.89, 128.18, 119.14, 77.28, 70.82, 51.93, $50.73,47.58,44.95,42.48,21.85,21.49$.

HRMS (ESI): $m / z$ [M + H] $]^{+}$calcd for $\mathrm{C}_{25} \mathrm{H}_{30} \mathrm{~N}_{5} \mathrm{O}_{6} \mathrm{~S}_{2}: 560.16320$; found: 560.16186.

\section{Acknowledgment}

We acknowledge Dr. Frédéric Montigny (Tours University) for recording mass spectra and HRMS and Dr. Karen Wright (Versailles University) for proof-reading the manuscript.

\section{Supporting Information}

Supporting information for this article is available online at https://doi.org/10.1055/s-0037-1610399.

\section{References}

(1) Agarwal, R.; Ansari, M. H.; Khan, M. W. Y.; Ahmad, M.; Sharma, K. D. J. Am. Oil Chem. Soc. 1989, 66, 825 . 
(2) Gonzalez, A. Z.; Eksterowicz, J.; Bartberger, M. D.; Beck, H. P.; Canon, J.; Chen, A.; Chow, D.; Duquette, J.; Fox, B. M.; Fu, J.; Huang, X.; Houze, J. B.; Jin, L.; Li, Y.; Li, Z.; Ling, Y.; Lo, M.-C.; Long, A. M.; McGee, L. R.; McIntosh, J.; McMinn, D. L.; Oliner, J. D.; Osgood, T.; Rew, Y.; Saiki, A. Y.; Shaffer, P.; Wortman, S.; Yakowec, P.; Yan, X.; Ye, Q.; Yu, D.; Zhao, X.; Zhou, J.; Olson, S. H.; Medina, J. C.; Sun, D. J. Med. Chem. 2014, 57, 2472.

(3) Duang, Y.-C.; Ma, Y.-C.; Zhang, E.; Shi, X.-J.; Wang, M.-M.; Ye, X.W.; Liu, H.-M. Eur. J. Med. Chem. 2013, 62, 11.

(4) Haider, S.; Alam, M. S.; Hamid, H.; Shafi, S.; Nargotra, A.; Mahajan, P.; Nazreen, S.; Kalle, A. M.; Kharbanda, C.; Ali, Y.; Alam, A.; Panda, A. K. Eur. J. Med. Chem. 2013, 70, 579.

(5) Piotrowska, D. G.; Balzarini, J.; Glowacka, I. E. Eur. J. Med. Chem. 2012, 47, 501.

(6) Phillips, O. A.; Udo, E. E.; Abdel-Hamid, M. E.; Varghese, R. Eur. J. Med. Chem. 2009, 44, 3217.

(7) Others applications: Chinthala, Y.; Domatti, A. K.; Sarfaraz, A.; Singh, S. P.; Arigari, N. K.; Gupta, N.; Satya, S. K. V. N.; Kumar, J. K.; Khan, F.; Tiwari, A. K.; Paramjit, G. Eur. J. Med. Chem. 2013, $70,308$.

(8) Delaye, P.-O.; Petrignet, J.; Thiery, E.; Thibonnet, J. Org. Biomol. Chem. 2017, 15, 7290.

(9) Poornachandran, M.; Raghunathan, R. Tetrahedron 2008, 64, 6461.

(10) Yeom, C.-E.; Kim, M. J.; Kim, B. M. Tetrahedron 2007, 63, 904.

(11) (a) Cocker, W. J. Chem. Soc. 1943, 373. (b) Olier, C.; Azzi, N.; Gil, G.; Gastaldi, S.; Bertrand, M. P. J. Org. Chem. 2008, 73, 8469.

(12) Belmessieri, D.; Cordes, D. B.; Slawin, A. M. Z.; Smith, A. D. Org. Lett. 2013, 15, 3472.

(13) Feula, A.; Dhillon, S. S.; Byravan, R.; Sangha, M.; Ebanks, R.; Salih, M. A. H.; Spencer, N.; Male, L.; Magyary, I.; Deng, W.-P.; Müller, F.; Fossey, J. S. Org. Biomol. Chem. 2013, 11, 5083.

(14) Kumar, S.; Mujahid, M.; Verma, A. K. Org. Biomol. Chem. 2017, $15,4686$.

(15) Liu, H.; Pan, Y.; Tan, C.-H. Tetrahedron Lett. 2008, 49, 4424.

(16) Liu, H.; Tan, C.-H. Tetrahedron Lett. 2007, 48, 8220.

(17) For recent iodocyclizations, see: (a) Grandclaudon, C.; Michelet, V.; Toullec, P. Y. Synlett 2018, 310. (b) Zhou, Y.; Zhang, X.; Zhang, Y.; Ruan, L.; Zhang, J.; Zhang-Negrerie, D.; Du, Y. Org.
Lett. 2017, 19, 150. (c) Garcia-Garcia, P.; Sanjuan, A. M.; Rashid, M. A.; Martinez-Cuezva, A.; Fernandez-Rodriguez, M.; Rodriguez, F.; Sanz, R. J. Org. Chem. 2017, 82, 1155. (d) Kamesu, K.; Krishnamohan, G. V.; Rajasekhar, K. Asian J. Chem. 2017, 29, 2704. (e) Sonawane, A. D.; Garud, D. R.; Udagawa, T.; Koketsu, M. Org. Biomol. Chem. 2018, 16, 245.

(18) (a) Zhang, X.; Zhou, Y.; Wang, H.; Guo, D.; Ye, D.; Xu, Y.; Jiang, H.; Liu, H. Adv. Synth. Catal. 2011, 353, 1429. (b) Alvarez-Corral, M.; Munoz-Dorado, M.; Rodriguez-Garcia, I. Chem. Rev. 2008, 3174.

(19) Heasley, V. L.; Shellhamer, D. F.; Heasley, L. E.; Yaeger, D. B.; Heasley, G. E. J. Org. Chem. 1980, 45, 4649.

(20) Singh, M. S.; Chowdhurry, S. RCS Adv. 2012, 2, 4547.

(21) (a) Ugi, I. Pure Appl. Chem. 2001, 73, 187; and references therein. (b) Multicomponent Reactions; Zhu, J.; Bienayme, H., Ed.; Wiley VCH: Weinheim, Germany, 2005.

(22) (a) Kumar, D.; Patel, G.; Reddy, V. B. Synlett 2009, 399. (b) Alonso, F.; Moglie, Y.; Radivoy, G.; Yus, M. Synlett 2012, 2179. (c) Mukherjee, N.; Ahammed, S.; Bhadra, S.; Ranu, B. C. Green Chem. 2013, 15, 389. (d) Feldman, A. K.; Colasson, B.; Fokin, V. V. Org. Lett. 2004, 6, 3897. (e) Safa, K. D.; Mousazadeh, H. Synth. Commun. 2016, 46, 1595. (f) Guo, S.; Zhou, Y.; Dai, B.; Huo, C.; Liu, C.; Zhao, Y. Synthesis 2018, 50, 2191.

(23) Yi, M.; Gu, P.; Kang, X.-Y.; Sun, J.; Li, R.; Li, X.-Q. Tetrahedron Lett. 2014, 55, 105.

(24) Patonay, T.; Juhàsz-Toth, E.; Bènyei, A. Eur. J. Org. Chem. 2002, 285.

(25) (a) Hassan, S.; Muller, T. J. J. Adv. Synth. Catal. 2015, 357, 617. (b) Baltus, C. B.; Jorda, R.; Marot, C.; Berk, K.; Bazgier, V.; Krystof, V.; Prié, G.; Viaud-Massuard, M. C. Eur. J. Org. Chem. 2016, 701. (c) Camp, C.; Dorbes, S.; Picard, C.; Benoist, E. Tetrahedron Lett. 2008, 49, 1979. (d) Mishra, K. B.; Tiwari, V. K. J. Org. Chem. 2014, 79, 5752. (e) Shamim, A.; Vasconcelos, S. N. S.; De Oliveira, I. M.; Reis, J. S.; Pimenta, D. C.; Zukerman-Schpector, J.; Stefani, H. A. Synthesis 2017, 5183. (f) Martinelli, M.; Milcent, T.; Ongeri, S.; Crousse, B. Beilstein J. Org. Chem. 2008, 4, 19. 